\title{
Core Self Evaluation pada Kinerja Karyawan Perusahaan X Kota Pekanbaru
}

\author{
Alma Yulianti \\ Fakultas Psikologi UIN Sultan Syarif Kasim Riau \\ email: yulianti.psikologi@gmail.com
}

\begin{abstract}
Abstrak
Artikel INFO

Diterima:25 Juni 2020

Direvisi :27 Agustus 2020

Disetujui: 26 Nov 2020

DOI:

http://dx.doi.org/10.24014/ jp.v14i2.10061

Seseorang yang tidak mampu mengevaluasi dan mengenali potensi kerja dirinya akan merugikan dirinya sendiri dan perusahaan. Strategi core self evaluation merupakan salah satu upaya dalam menumbuhkan kinerja individu salah satu urgensi dalam penelitian ini. Penelitian ini melibatkan seluruh karyawan Perusahaan X di Kota Pekanbaru, pengambilan sampel menggunakan Proportionate Stratified Random Sampling untuk menetapkan subjek penelitian guna penetapan sampel dan dasar perhitungan yang mewakili jumlah level manajemen pada perusahaan tersebut. Elemen populasi dibagi menjadi beberapa tingkatan (stratifikasi) berdasarkan karakter yang melekat padanya, yaitu level manajemen yaitu menengah dan level manajemen bawah. Menggunakan pengambilan sampel 153 karyawan. Analisis korelasi Pearsons digunakan guna mencari keterkaitan. Hasil penelitian ini menunjukkan bahwa core self-evaluations mampu memprediksi kinerja dengan tingkat signifikan $0,011<0,05$. Hal ini menyatakan bahwa core self-evaluation memiliki hubungan yang positif dengan kinerja. Artinya, ketika hasil core self-evaluations tinggi maka karyawan akan mampu menghabiskan tingginya kualitas, energi, waktu, dan akan menetapkan sasaran di tempat kerja sebagai dinamika karir pada masa dewasa.
\end{abstract}

Kata kunci: core self-evaluations, kinerja, karyawan

\section{Core Self Evaluation on Employee Performance of Company $X$ in Pekanbaru}

\begin{abstract}
Individu can not to evaluate and recognize his work potential will backfire for his own performance and ultimately impact on the company's performance. The inability to formulate performance can happen to anyone and anywhere without knowing the status and position. Thus the core self-evaluation strategy is needed as an effort to create performance both for individual performance and team performance. The population of this study is all employees of Company X in Pekanbaru City, sampling using Proportionate Stratified Random Sampling to establish research subjects as a basis for calculation and determination of research samples that represent the number of samples and the number of levels of management at the company. The population element is divided into several levels (stratification) based on the characters attached to it, namely the management level, namely middle and lower management levels. Using sampling 153 employees. Pearsons correlation analysis is used to look for relationships. The results of this study indicate that core self-evaluations are able to predict performance with a significant level of $0.011<0.05$. This suggests that core self-evaluation has a positive relationship with performance. That is, when the core self-evaluations results are high then employees will be able to spend a lot of quality, energy, time, and will set high goals at work as career dynamics in adulthood.
\end{abstract}

Keywords: core self-evaluations, performance, employees

\section{Pendahuluan}

Indikator kesuksesan organisasi maupun institusi salah satunya tercermin pada kinerja yang dihasilkan secara berkesinambungan baik kinerja dari aspek finansial, aspek manusia, aspek metode kerja dan lingkungan yang kondusif. Kinerja sumber daya manusia (SDM) dipengaruhi oleh dua kategori faktor utama yaitu faktor internal dan faktor eksternal 
SDM (Kaushal dan Kwantes 20006).

Faktor internal SDM merupakan suatu keadaan atau kondisi yang ada dalam diri individu dan mempengaruhi secara horizontal pada kinerja. Faktor internal tersebut bisa meliputi pengetahuan, semangat, sikap, kepuasan, kedisiplinan, stress, komitmen dan masih banyak lainnya. Hal-hal tersebut tentu saling terkait dan memberikan dampak secara langsung yang signifikan bagi kemajuan organisasi atau lembaga. Begitu pula dengan faktor eksternal di mana suatu kondisi atau keadaan disekitar kita yang secara tidak langsung dapat memberikan pengaruh pada kinerja. Faktor eksternal tersebut meliputi lingkungan kerja, kebijakan pemerintah atau lembaga, adanya persaingan, sistem manajemen lembaga, budaya dan peran pemimpin serta faktor lainnya.

Rentang usia dewasa sebagai usia produktif pada karyawan identik dengan adanya perubahan secara fisiologis maupun psikologis. Masa ini diartikan sebagai meningkatkan keterampilan fisik dan semakin besarnya tanggung jawab, dimana individu mulai sadar akan polaritas serta makin berkurangnya jumlah waktu yang tersisa untuk kehidupan, salah satunya individu mencapai dan mempertahankan kepuasan dalam karir (Yulianti, 2013). Masa ini identik dengan masa eksplorasi karir ini dapat menjadi masa yang sulit bagi sejumlah individu. Tidak semua Individu dewasa dapat mengambil keputusan dengan mudah (Creed, Patton, \& Prideaux, 2006; Argyropoulou, Sidiropoulou-Dimakakao, \& Besevegis, 2007; Hirschi \& Lage, 2007). Fokus utama dari tahapan eksplorasi adalah menggali berbagai informasi diri serta bidang karir sebagai dasar menentukan pilihan karir tertentu. Eksplorasi karir yang dimaksud termasuk memilih karir yang sejalan dengan kehidupan individu yang dijalani (Super dalam Savickas, 2002). Individu maupun organisasi atau intistusi memperoleh dan menjaga keselarasan dengan menggunakan nilai, etika dan prinsip-prinsip utama. Keyakinan pribadi dan organisasi yang kita yakini inilah membentuk perkembangan karir.

Kinerja karyawan diartikan sebagai potensi dan kemampuan seorang karyawan dalam melakukan sesuatu keahlian tertentu yang dimiliki. Kemampuan maupun potensi yang dimiliki seorang karyawan dalam melaksanakan tugas yang dibebankan kepadanya dan mampu menyelesaikan dengan baik (Sinambela, 2009). Maka dari itulah dibutuhkan penentuan kriteria yang jelas, valid dan terukur serta ditetapkan secara bersamasama yang dijadikan sebagai pedoman maupun acuan dalam penetapan kinerja seorang karyawan.

Di Indonesia, sekitar $46 \%$ individu bekerja berada pada rentang usia 35-40 tahun. Di sisi lain individu yang tidak bekerja berkisar $20 \%$. Lebih dari $45 \%$ individu yang bekerja pada usia ini menyatakan bahwa kondisi kesehatan atau keterbatasan mereka memebatasi tipe pekerjaan yang dapat dilakukan mempengaruhi kinerja mereka sebagai karyawan (Stern \& Hyuk, 2011). Pekerja paruh baya menghadapi sejumlah tantangan penting yang meliputi globalisasi kerja, perkembangan teknologi informasi yang cepat, pengurangan ukuran organisasi, pensiun dini dan juga keperawatan kesehatan (Santrock, 2011).

Survei menyebutkan sekitar $11 \%$ karyawan maupun karyawati yang merasakan kejenuhan ditempat bekerja dan sulit bangkit dari kejenuhan karena pekerjaan yang rutinitas di organisasinya. Para peneliti mengolah data berdasarkan survei karyawan dan karyawai dari 61 negara pada 2012 hingga 2015 dan mendapati hasil bahwa Indonesia memiliki angka rata-rata $15 \%$ untuk karyawan dan sedikitnya $8 \%$ pada karyawati (dhttps://www. cnnindonesia.com/gaya-hidup-pekerja)

De Jong dan Hertog (2010) memaparkan efektifitas pada kinerja berhubungan dengan pengamatan pada pekerja dalam mengantisipasi permasalahan pekerjaan dan 
respon rekan kerja terhadap alternatif solusi yang diajukan. Perilaku kinerja yang inovatif membutuhkan komitmen, keterlibatan, dan kepemimpinan manajemen dalam mengembangkan faktor penunjang baik yang bersifat teknikal dan non teknikal dalam suatu pekerjaan (Prijono, 2011).

Kinerja adalah suatu konsep yang multidimensional mencakup tiga aspek yaitu sikap (attitude), kemampuan (ability) dan prestasi (accomplishment). Sementara Mangkuprawira dan Hubeis (2007) mengatakan bahwa kinerja adalah hasil dari proses pekerjaan tertentu secara terencana pada waktu dan tempat dari karyawan serta organisasi bersangkutan. Kinerja karyawan tidak hanya sekedar informasi untuk dapat dilakukannya promosi atau penetapan gaji bagi perusahaan. Akan tetapi bagaimana perusahaan dapat memotivasi karyawan dan mengembangkan satu rencana untuk memperbaiki kinerja. Ukuran kinerja dapat dilihat dari sisi jumlah dan mutu tertentu sesuai dengan standar yang telah ditetapkan oleh organisasi atau perusahaan bentuknya dapat bersifat tangible (dapat ditetapkan alat ukurnya atau standarnya) atau intangible (tak dapat ditetapkan alat ukurnya atau standarnya), tergantung pada bentuk dan proses pelaksanaan pekerjaan itu.

Kajian penelitian yang berjudul Core Self Evaluations menemukan bahwa Core Self Evaluation mampu menjelaskan kepribadian pekerja dan memprediksi perilaku kerja sehingga mencapai optimalisasi kepuasan kerja pada individu (Judge, 2009). Mengingat pentingnya peran kinerja karyawan bagi keberhasilan organisasi, pemahaman terkait faktor-faktor yang dapat meningkatkan hasil kenerja karyawan itu sendiri menjadi sangatlah krusial dan esensial khususnya dalam ekplorasi karir individu di masa dewasa. Salah satu faktor yang mempengaruhi kinerja karyawan yang dilakukan oleh individu adalah Core Self Evaluations. Core Self Evaluations merupakan sifat kepribadian yang berhubungan dengan kemampuan individu dalam melakukan kontrol terhadap perilakunya (Robbins dan Judge, 2006). Core Self Evaluations menggambarkan sejauh mana individu menyukai atau tidak menyukai diri sendiri, menganggap diri efektif, cakap dan mampu mengendalikan lingkungan. Individu yang memilki self esteem atau harga diri yang tinggi akan menghargai dirinya sendiri, penghargaan terhadap diri sendiri akan mendukung sikap yang positif pula terhadap kinerja karyawan.

Oleh karena itu penelitian ini bertujuan untuk mengetahui peran faktor kepribadian dalam hal ini Core Self Evaluations sebagai prediktor kinerja pada karyawan. Adapun rumusan permasalahan yang diajukan dalam penelitian adalah apakah ada kontribusi peran Core Self Evaluations dalam memprediksi Kinerja Karyawan Persusahaan X di Kota Pekanbaru. Secara teoritis, penelitian ini diharapkan dapat memberikan manfaat untuk pengembangan ilmu Psikologi, khususnya pada bidang Psikologi Sosial dan Pengembangan Karir dalam melihat Peran Core Self Evaluations dalam memprediksi kinerja karyawan. Tahapan perilku ini adalah proses yang harus dilalui karyawan dalam mengembangkan perilaku kerja yang ideal sebagai indikator pengukuran kinerja.Pengukuran kinerja karyawan merupakan sejauh mana individu telah memainkan baginya dalam melaksanakan strategi organisasi, baik dalam mencapai sasaran khusus yang berhubungan dengan peran perorangan atau memperlihatkan kompetensi yang dinyatakan relevan bagi organisasi.

\section{Kinerja Karyawan}

Kinerja didefenisikan dalam cara yang fundamental, mempengaruhi kondisi finasial mereka sampai ketahap merefleksikan pekerjaan sebagai bentuk prestasi. Kinerja karyawan adalah kemampuan karyawan secara keseluruhan selama periode tertentu 
didalam melaksanakan tugas, seperti standar hasil kerja, target atau sasaran kriteria yang telah ditentukan terlebih dahulu dan telah disepakati bersama (Veithzal, 2005). Indikator untuk mengukur kinerja karyawan secara individu terurai dalam enam indikator (Robbins, 2006) antara lain: (1) Kualitas, kualitas kerja diukur dari persepsi para pegawai terhadap kualitas yang telah dihasilkan Kuantitas, merupakan jumlah yang dihasilkan pegawai, dinyatakan dalam istilah seperti jumlah unit, jumlah siklus aktivitas yang telah diselesaikan. (2) Ketepatan waktu, merupakan tingkat aktivitas dalam penyelesaian pekerjaan sesuai dengan waktu yang telah ditetapkan, dilihat dari sudut koordinasi dengan hasil output serta pemaksimalan waktu yang tersedia untuk aktivitas lain. (3) Efektivitas, merupakan tingkat penggunaan sumber daya organisasi (tenaga, uang, teknologi, dan bahan baku) yang dilakukan secara maksimal dengan tujuan untuk menaikkan hasil dari setiap unit di dalam penggunaan sumber daya. (4) Kemandirian, merupakan tingkat pegawai yang dapat menjalankan fungsi kerjanya sesuai komitmen kerja. Kemandirian merupakan suatu tingkat dimana pegawai mempunyai komitmen dan tanggung jawab pegawai terhadap perusahaan.

\section{Core Self Evaluations (CSE)}

Core Self Evaluations merupakan sifat kepribadian yang berhubungan dengan kemampuan individu dalam melakukan kontrol terhadap perilakunya (Robbins dan Judge, 2006). Core Self Evaluations (CSE) merupakan tingkatan dimana individu menyukai atau tidak menyukai diri sendiri, menganggap diri efektif, cakap dan mampu mengendalikan lingkungan (Judge, dkk, 2003). CSE mengandung empat elemen keribadian yaitu general self efficacy, self esteem, emotional stability dan locus of control. Core Self Evaluations
(CSE) menggambarkan keyakinan individu mengenai kemampuannya (untuk mengontrol hidupnya) dan kompetensinya (untuk berperilaku, mengatasi, gigih dan berhasil dalam berperilaku) dan perasaan kehidupannya yang ditentukan oleh diri sendiri (Judge, 2009). Hasil penelitian telah menunjukkan bahwa CSE yang tinggi berhubungan positif dengan besarnya usaha para karyawan dalam meningkatakan perilaku inovatif dan kinerjanya dan melebihi variabeldemografis (Muratore \& Earl, 2010 ). CSE adalah merupakan tingkatan dimana individu menyukai atau tidak menyukai diri sendiri, menganggap diri efektif, cakap dan mampu mengendalikan lingkungan (Judge, dkk 2003). Inidividu dengan CSE yang tinggi akan melakukan usaha yang lebih besar untuk menyiapkan kinerjanya diorganisasi. Individu yang memiliki evaluasi atau penilaian diri yang positif atas dirinya akan mampu menghargai dirinya, memiliki keyakinan akan bahwa dirinya mampu menghadapi tantangan pekerjaan dan memiliki kemampuan untuk mengatasi permasalahan dan tetap tenang menghadapi masa-masa sulit dalam bekerja. Keyakinan bahwa dirinya yang menentukan nasibnya akan membuatnya melakukan usaha-usaha yang lebih untuk menyiapkan diri menghadapi tantangan-tangan pekerjaan. Kinerja organisasi yang baik tidak terlepas dari kinerja karyawan yang baik pula. intensi yang dimiliki dipengaruhi oleh sikap, norma subjektif dan persepsi terhadap kemampuannya dalam melakukan kontrol (Ajzen, 1991). CSE merupakan sifat kepribadian yang berhubungan dengan kemampuan individu dalam melakukan kontrol terhadap perilakunya (Robbins, 2006). Dalam tahapan perkembangan generasi saat ini memiliki pengalaman-pengalaman pekerjaan yang menekankan pada orienstasi kognitif. Seiring dengan transisi masyarakat industri menuju manyarakat informatif, usia dewasa madya memiliki lebih banyak pengalaman kerja yang membutuhkan investasi kognitif (Santrock, 
2011) Meningkatkan penekatan terhadap pengolahan informasi dalam pekerjaan yang diikuti dengan peningkatan kemampuan intelektual individu (Kristujuhan \& Taidre, 2008). Dalam tahapan perkembangan karir individu, kinerja karyawan maupun karyawati terjadi pada tahap akhir, dimana individu tidak lagi terlibat dalam peran maupun tanggung jawab pada organisasi. Sebagai bagian dari tahapan karir yang pasti akan dilalui individu, maka seharusnya individu sudah menyiapkan tahap ini sebelumnya. Besarnya usaha yang dilakukan individu untuk menyiapkan tantangan dipekerjaannyaakan membantu individu untuk mencapai kinerja yang optimal dan diingankin organisasi maupun perusahaan.

Pada masa dewasa madya keahlian karyawan baik pria maupun wanita membutuhkan waktu untuk mempertahankannya dibandingkan pada waktu dewasa awal. Mengembangkan keahlian disuatu orgtanisasi biasanya merupakan hasil dari pengalaman, belajar, dan usaha selama bertahun-tahun. Perbedaan strategi ini meliputi beberapa hal, antara lain :a) dalam menyelesaikan masalah dibidang kerja, individu usia dewasa madya lebih banyak mendasarkan pada akumulasi pengalaman mereka, b) dalam memecahkan masalah dibidangnya, individu usia dewasa madya sering memproses informasi secara otomatis dan menganalisis secara efektif dibandingkan orang-orang baru atau usia dewasa awal yang baru bergabung diusia angkatan kerja, c)dalam memecahkan masalah, inidividu usia dewasa madya memiliki strategi yang lebih baik dan singkat dibandingkan usia angkatan kerja lainnya, d) dalam memecahkan masalah, individu dewasa madya memiliki keahlian lebih kreatif dan fleksibel dibandingkan usia angkatan kerja lainnya.

Logika dan dasar di atas yang menjadi prediksi peneliti bahwa kinerja Karyawan Perusahaan $\mathrm{X}$ dalam konteks berada pada usia dewasa madya sebagaimana usia ini sebagai usia produktif, ditentukan pula oleh usia angkatan kerja yaitu berada pada usia dewasa madya yang mana dalam memecahkan masalah berdasarkan pada pemrosesan informasi yang berada pada ranah kognitif salah satunya bersumber dari core self evaluations diri pribadi tersebut, hal ini sejalan dengan konsep ekplorasi karir pada masa dewasa.Model Hipotesis pertama: Terdapat pengaruh yang signifikan dari Core Self Evaluations Terhadap Kinerja Karyawan Perusahaan X di Kota Pekanbaru. Model Hipotesis kedua: Terdapat pengaruh yang signifikan dari Core Self Evaluations terhadap Level Manajemen.

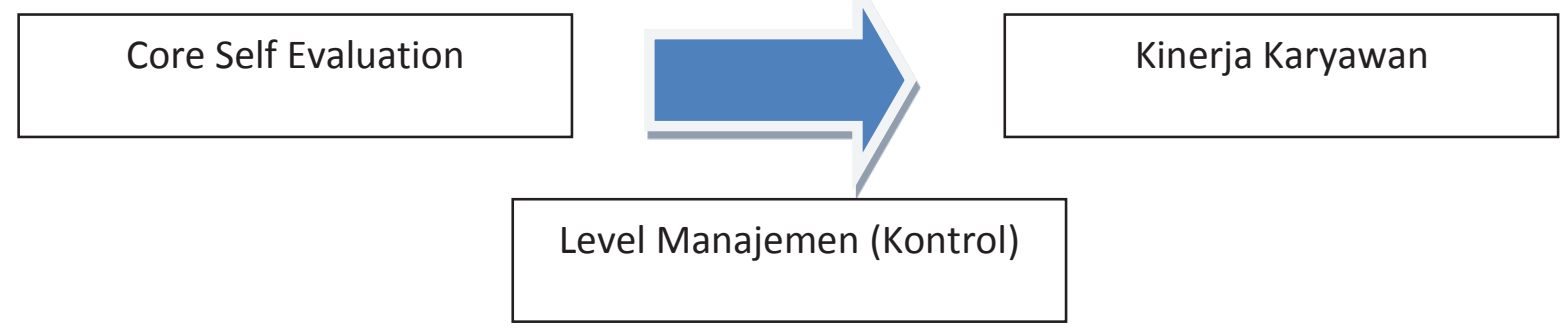

Bagan 1 Skema Hubungan Core Self Evaluation kepada Kinerja Karyawan dengan Kontrol pada Level Manajemen

\section{Metode}

Penelitian ini merupakan penelitian deskriptif korelasional, dimana yang ingin menguji secara empirik hubungan antara variabel-variabel yang diajukan. Desain penelitian ini menggunakan metode kuantitatif, dengan metode kuantitatif akan diperoleh siginifikansi hubungan variabel yang diteliti (Azwar, 2013). Teknik yang digunakan dalam 
penelitian ini adalah korelasi.

\section{Partisipan}

Sampel dalam penelitian ini dengan total 153 karyawan yang berada pada level manajemen menengah dan rendah (Hurlock, 1999); termasuk ke dalam kategori usia dewasa dalam rentang usia produktif pada pencapaian karir, yang tergabung dalam kelompok pekerja produktif. Dengan metode Harry King dan agar sampel penelitian dapat mewakili keseluruhan populasi, maka ditetapkan $15 \%$ dengan tingkat kepercayaan lima persen sebagai acua yang dianggap layak dalam menetapkan sampel pada keseluruhan populasi (Sugiyono, 2003). Untuk memperoleh keterwakilan sampel pada keseluruhan populasi, maka Proportionate Stratified Random Sampling digunakan oleh peneliti untuk menetapkan subjek penelitian sebagai dasar perhitungan dan penetapan sampel penelitian yang mewakili jumlah tenaga kependidikan dan jumlah level manajemen dari masing-masing prodi yang terlibat dalam penelitian ini yang berjumlah subjek penelitian sebagai dasar penetapan sampel penelitian yang mewakili jumlah tenaga kependidikan yang terlibat dalam penelitian ini. Proportionate Stratified Random Samplingadalah salah satu tehnik pengambilan sampel dengan memperhatikan suatu tingkatan (strata) pada elemen populasi. Elemen populasi dibagi menjadi beberapa tingkatan (stratifikasi) berdasarkan karakter yang melekat padanya, yaitu level manajemen yaitu level manajemen menengah dan level manajemen bawah.

\section{Pengukuran}

Intrumen penelitian ini yang digunakan berisi sejumlah daftar pertanyaan yang penyusunannya berdasarkan skala likert. Khusus untuk mengungkap core self evaluation pada empat dimensi pengukuran, seperti self efficacy, emotional stability, self esteem, dan locus of control menggunakan model analisis confirmatory factor analysis, diperoleh hasil bahwa semua dimensi tersebut memiliki pengaruh terhadap kinerja subjek penelitian dengan tingkat signifikansinya $p<0.001$. Sedangkan uji korelasi antar core self evaluations dengan kinerja menunjukkan hasil yang signifikan dengan koefisien korelasi bergerak antara 0,337 hingga 0,528. Sebelumnya responden diberikan informasi terkait dengan pengisian kuesioner penelitian dan prosedur mengerjakan serta penjelasan informed consent, yaitu kerahasiaan data dari subjek penelitian selama penelitian berlangsung.Khususnya yang mengungkap perilaku Core Self Evaluations dan Kinerja.

Skala Core Self Evaluation terdiri atas 34 item yang mengukur empat komponen yaitu self esteem, self efficacy, locus of control dan emotional stability, dengan reliabilitas sebesar 0,83. Sedangkan skala pengukuran Kinerja menggunakan konsepsi pemikiran dari Robbins (2006) yang dalam penetapan dimensi skala pengukuran yang telah dimodifikasi oleh peneliti berjumlah 10 item , reliabilitas sebesar 0,90. dan menyesuaikan dengan kondisi saat ini, agar memiliki kesesuaian dengan budaya organisasi dan praktek manajemen yang menekankan pentingnya kontribusi kinerja

\section{Hasil}

Analisis data dilakukan dengan beberapa tahapan yaitu pengumpulan data, pengecekkan kembali data yang terkumpul, melakukan skor dan tabulasi dari kuesioner yang digunakan, kemudian menyesuaikan print-out dengan data yang ada dalam tabulasitersebut.Dari hasil pengumpulan data, merupakan representasi level manajemen menengah dan bawah adalah posisi pelaksana akademik maupun administrasi, sehingga keseluruhan sampel penelitian yang diikut sertakan dalam analisis berjumlah 153 subjek. Pengolahan data dilakukan melalui bantuan program SPSS (Statistical Product And Service Solution) versi 20,00 untuk 
menganalisis pola hubungan antara variabel penelitian.

Analisis yang dilakukan untuk menguji hipotesis $\mathrm{H} 1$, yaitu core self-evaluations berhubungan dengan kinerja secara signifikan dengan menggunakan metode analisis korelasi by Pearson. Berdasarkan analisis hubungan Pearson Product Moment dalam memperoleh hubungan antara variabel penelitian diperoleh hasil seperti berikut :

Tabel 1. Pola Hubungan Antar Aspek Variabel Penelitian

\begin{tabular}{|c|c|c|c|c|c|c|c|c|c|}
\hline \multicolumn{2}{|c|}{$\begin{array}{l}\text { Variabel } \\
\text { Penelitian }\end{array}$} & \multirow{2}{*}{$\begin{array}{c}\mathbf{N} \\
153\end{array}$} & \multirow{2}{*}{$\begin{array}{c}\begin{array}{c}\text { Jumlah } \\
\text { Item }\end{array} \\
34\end{array}$} & \multirow{2}{*}{$\begin{array}{c}\text { Mean } \\
3,85\end{array}$} & \multirow{2}{*}{$\begin{array}{c}\begin{array}{c}\text { Self } \\
\text { Eficacy }\end{array} \\
1\end{array}$} & \multirow{2}{*}{$\begin{array}{c}\begin{array}{c}\text { Emotional } \\
\text { Stability }\end{array} \\
.502\end{array}$} & \multirow{2}{*}{$\begin{array}{c}\begin{array}{c}\text { Self } \\
\text { Esteem }\end{array} \\
.595\end{array}$} & \multirow{2}{*}{$\begin{array}{c}\begin{array}{c}\text { Locus } \\
\text { of } \\
\text { Control }\end{array} \\
.469\end{array}$} & \multirow{2}{*}{$\begin{array}{r}\text { Kinerja } \\
.528\end{array}$} \\
\hline $\begin{array}{l}\text { Core Self } \\
\text { Evaluation }\end{array}$ & $\begin{array}{l}\text { Self } \\
\text { Eficacy }\end{array}$ & & & & & & & & \\
\hline & $\begin{array}{l}\text { Emotional } \\
\text { Stability }\end{array}$ & & & 3,88 & .502 & 1 & .509 & .282 & .400 \\
\hline & $\begin{array}{l}\text { Self } \\
\text { esteem }\end{array}$ & & & 3,77 & .595 & .509 & 1 & .434 & .337 \\
\hline & $\begin{array}{l}\text { Locus Oof } \\
\text { Control }\end{array}$ & & & 3,70 & .469 & .282 & .434 & 1 & .458 \\
\hline Kinerja & & 153 & 10 & 3,90 & .528 & .400 & .337 & .458 & 1 \\
\hline
\end{tabular}

Gambar 1 di atas menjelaskan korelasi antar aspek variabel peneltian dimana koefisien korelasi seluruhnya signifikan pada tingkat 0,01 . Maka hasil temuan empiris menjelaskan sebagai berikut :

1. Koefisien korelasi sebesar .528 menunjukkan bahwa ada hubungan signifikan antara self eficacy dengan kinerja pada karyawan.

2. Koefisien korelasi sebesar .400 memberikan penjelasan bahwa ada hubungan signifikan antara Emotional Stability dengan kinerja pada karyawan.

3. Koefisien korelasi sebesar .337 menerangkan bahwa ada hubungan signifikan antara Self Esteem dengan kinerja pada karyawan.

4. Koefisien korelasi sebesar .458 menunjukkan bahwa ada hubungan signifikan antara Locus Of Control dengan kinerja pada karyawan.

Tujuan utama dari penelitian ini adalah untuk membuktikan secara empirik apakah core self evaluations berhubungan kinerja
Karyawan Perusahaan $\mathrm{X}$ dengan melibatkan level manajemen sebagai mediator. Hasil penelitian ini menemukan bahwa core self evaluation tidak dapat dipisahkan dengan aspek-aspek yang menyertainya.

Berdasarkan analsiis data diketahui bahwa nilai koefisien penentu atau $\mathrm{R}$ Square adalah sebesar 0.361 . Hal ini berarti kinerja dapat dijelaskan oleh variabel independen core self-evaluations sebesar $36,1 \%$, sedangkan sisanya $63,9 \%$ dipengaruhi faktor lain yang tidak diteliti oleh peneliti. Core self-evaluations sebagai variabel bebas menunjukkan adanya pengaruh yang signifikan dengan kinerja Karyawan Perusahaan $X$ dengan tingkat signifikan $0,011<0,05$. Hal ini menyatakan bahwa core self-evaluations memiliki hubungan yang positif dengan kinerja. Artinya, ketika hasil core self-evaluations tinggi maka karyawan akan mampu menghabiskan banyak kualitas, energi, waktu, dan akan menetapkan sasaran tinggi di tempat kerja.Salah satu komponen aspek dari Core self-evaluations yaitu self menunjukkan adanya pengaruh yang signifikan dengan kinerja sebagai variabel terikat dengan tingkat signifikan 
$0,000<0,05$. Hal ini menyatakan bahwa self efficacy memiliki hubungan yang positif dengan kinerja, artinya self efficacy dalam diri Karyawan tinggi maka diikuti dengan tinggi tingkat kinerja. Keyakinan dalam menjalankan tugas menjadi hal terpenting dalam memprediksi kinerja dibandingkan aspek core self evaluations lainnya.

\section{Pembahasan}

Core Self Evaluations merupakan sifat kepribadian yang berhubungan dengan kemampuan individu dalam melakukan kontrol terhadap perilakunya (Robbins dan Judge, 2006). Core Self Evaluation menggambarkan sejauh mana individu menyukai atau tidak menyukai diri sendiri, menganggap diri efektif, cakap dan mampu mengendalikan lingkungan. Individu yang memilki self esteem atau harga diri yang tinggi akan menghargai dirinya sendiri, penghargaan terhadap diri sendiri akan mendukung sikap yang positif pula terhadap kinerja karyawan. Meningkatkan keterampilan dan keyakinan dalam mengharagai diri sendiri dan melakukan sesuai kemamapuan yang diliki oleh seorangt pegawai atau dalam hal ini karyawan Perusahaan $X$ dan semakin besarnya tanggung jawab, dimana individu mulai sadar akan polaritas serta makin berkurangnya jumlah waktu yang tersisa untuk kehidupan, salah satunya individu mencapai dan mempertahankan kepuasan dalam karir (Yulianti, 2013).

Individu maupun organisasi atau intistusi memperolehdanmenjagakeselarasandengan menggunakan nilai, etika dan prinsip-prinsip utama. Keyakinan pribadi dan organisasi yang kita yakini inilah membentuk perkembangan karir dan menunjang kinerja mereka secara berarti dan bermakna. Keterbatasan dalam penelitian adalah penggunaan kata "terlalu" pada alat ukur Kinerja. Penggunaan kata ini rentan mengalami kontaminasi dari sumber lainnya (steel, 2002). Beberapa subjek mengalami kesulitan dalam memahami skala yang disajikan. Instrument ini sesuai dengan bentuk aslinya dan peneliti melakukan pre-liminier mengingat subjek penelitian berada dalam usia dewasa madya. Bila tiap pertanyaan untuk Core Self Evaluation diberi pilihan, maka skala yang disajikan pada subjek akan terlihat semakin tebal dan membosankan. Terkait hasil penelitian di atas dapat direkomendasikan model karir bagi karyawan.

Model yang sesuai untuk mengatasi hambatan-hambatan dalam pengambilan keputusan karir bagi karyawan salah satunya melalui pendekatan Career Information Processing Model. Pendekatan ini adalah pendekatan yang menekankan pikiran dan memori dalam proses menyelesaikan masalah dan mengambil keputusan sesuai dengan karakteristik perkembangan kognitif pada fase dewasa yaitu proses Hypothesis Deduktif salah satunya pada perkembangan karir. Pendekatan career information processing model akan dijadikan pendekatan dalam konseling karir. Pendekatan career information processing merupakan integrasi dari teori pemecahan masalah karir yang berasal dari psikologi kognitif dengan perspektif dari pemrosesan informasi individu dalam memilih karir dan mengambil keputusa. Pendekatan ini memiliki bertujuan memfasilitasi individu pekerja atau karyawan untuk menjadi problem solver (pemecah masalah) dan pengambil keputusan yang lebih baik (Patton dan McMahon, 2014).

\section{Kesimpulan}

Berdasarkan hasil penelitian dan analisis data yang diperoleh dari responden, penulis dapat mengambil simpulkan beberapa hal berikut. Variabel core self-evaluations berhubungan secara signifikan kinerja Karyawan Perusahaan X di Kota Pekanbaru. Komponen Self Efficacy memiliki peranan yang dominan pada core self evaluations subjek penelitian, diikuti dengan komponen Self Esteem yang ada di dalam diri subjek. Komponen ini menjelaskan bahwa kinerja ditentukan salah satunya oleh komponenkomponen core self evaluations yaitu self efficacy dan self esteem pada Karyawan Perusahaan $\mathrm{X}$. 
Merujuk pada hasil penelitian, maka saran yang dapat diajukan. Pertama, melibatkan partisipasi dengan level manajamen puncak dan masa kerja dari karyawan yan $\mathrm{g}$ ingin diukur sehingga lebih bervariasi dalam memperkaya hasil penelitian. Kedua, Organisasi atau institusi perlu mempertahankan dan meningkatkan aspek core self-evaluatios dan kinerja karena semakin tinggi nilai core self-evaluations diikuti tingginya kinerja pada karyawan. Strategi yang telah dilakukan adalah tempat kerja yang nyaman, lingkungan kerja yang berkerabat, memberikan bonus, dan memberikan pelatihan-pelatihan untuk meningkatkan self efficacy dan self esteem Karyawan.

\section{Daftar Pustaka}

Ajzen, I. 1991. Theory of Planned Behavior. Organizational Behavior and Human Decision Processes. 50, 179-211.

De Jong, J \& Den Hartoq, D. 2010. Measuring Inovative Work Behavior. Journal Of Creativity AnInovation Management, 19, (1), 23-26.

Judge, T.A 2009. Core Self-Evaluations and Work Success. Journal Of The Association For Psychological Science. Vol 18 number1.

Hurlock, Elisabeth B. 1999. Psikologi Perkembangan, Suatu Pendekatan Sepanjang Rentang Kehidupan. Alih bahasa,Istiwidayanti, Soedjarwo, Jakarta: Erlangga.

Levenson. H. 1981. Differentiating Among Internality, Powerful Others, And Chance. In H.M.Lefcourt (Ed.), Research With The Locus Of Control Construct: Vol. 1. Assessment Methods. New York: Academic Press.

Miller, D. T. \& Prentice, D. A. (2013). Psychological Levers Of Divide Hypothesis. In Cultural Divides.

Monks, FJ., A.M.P.Knoers. Siti Rahayu Haditomo. 2002. PsikologiPerkembangan

Pengantar dalam Berbagai Bagiannya. Yogyakarta: Gadjah Mada University Press.
Muratore \& Earl J. K. 2010. Employment Financial Preparation: Implications For Policy.

Journal of Aging and Social Policy, 16, 19-34 Prijono Sugiarto (21 Februari 2011). Net Quality Income Astra Capai Rp.4 Miliar. Diunduh

20 September 2019, dari http://www. infobanknews.com

Rivai, Veithzal, 2005. Manajemen Sumber Daya Manusia untuk Perusahaan, dari Teori ke

Praktik, PT. Raja Grafindo Persada, Jakarta.

Robbins, P. Stephen, (2006). Oranisation Behavior. Edisi 9, New jersey, Prentice Hall

Iternational Inc.

Rantelimbong, Octaviani \& Mas'ud, Fuad. 2016. Pengaruh Keterikatan Karyawan (Employee

Engagement) Terhadap Kinerja Karyawan : Peran Jarak Kekuasaan (Power

Distance)

Sebagai Moderator. Diponegoro Journal of Management, Volume 5, Nomor 3, Tahun 2016, Halaman 1-11.

Santrock, J.w. 2011. Life-Span Develoment. Perkembangan Masa Hidup. Jilid 2. Bandung.

Penerbit Erlangga

Schaufeli, W. B., dkk. (2006). Work Engagement: An Emerging Concept In Occupational

Health Psychology. Journal of Work and Stress, 22 (3), 187-200.

Sinambela, Lijan Poltak. (2012). Kinerja Pegawai Teori Pengukuran dan Implikasi.

Yogyakarta: Graha IImu.

Yulianti, A Wahyuni, S, Mukhlis. (2013). Psikologi Perkembangan. Penerbit Al Mujtahadah

Press. 